\title{
State Service and Redefinition of Religion
}

\author{
Hadi Satrio Leleno ${ }^{1}$, Riswadi ${ }^{2}$ \\ Borobudur University ${ }^{1,2}$ \\ \{hadiboro02@gmail.com¹,riswadi@borobudur.ac.id ${ }^{2}$ \}
}

\begin{abstract}
The definition of prevailing religion in general (world religions) has been constructed in such a manner by rulers' concept. Minority belief started alienated in a hometown. In the eyes of the sociology of religion, Durkheim gives the sense that religion is sui generis in a society. By using a qualitative approach and descriptive qualitative methods, the data obtained were analyzed using descriptive analysis, it was found that. Questioning the paradigm expansion in the definition of religion can be an alternative solution to redefine religion, so there is no longer growing "religion of government," "majority," and "minority" in the view of religion in Indonesia.
\end{abstract}

Keywords: Religion; Minority; Indonesian Society

\section{Introduction}

The definition of religion has been constructed in such a way as to suit the rulers. The rulers carried out paradigm contestation to be able to define religion according to its concepts and paradigms. About local and minority beliefs, import (newcomers) beliefs begin to oppress and dominate "the host". Before the import trust came, local beliefs had gained a place and had nurtured the people to become "religious" people. However, the politicization of immigrant religions into local beliefs is an enemy at home. They were starting from framing about the occult, mystical, syncretic, superstitious, and so on. Local beliefs began to be isolated in their territory. The root of the contestation of the religious paradigm here is a uniformity of the definition of religion [1].

In the perspective of the sociology of religion, one of the figures, Emile Durkheim, gave the understanding that religion is sui generis in a society. According to Durkheim, religion is a "system of beliefs and practices that have been united and are associated with sacred things, beliefs, and practices that unite into a single moral community". Religion does not have to involve the concept of a supernatural being. Still, it cannot let go of the two elements above because it will no longer be a religion when one of these elements is released. From this, it can be seen that something called religion is not seen from the substance of its content but from its form, which involves the two characteristics mentioned above. Several figures tried to define religion based on their understanding and research. Among them:

a. Spencer: religion contains the belief in something eternal and beyond intellect.

b. Max Muller: religion as an attempt to understand something that cannot be understood and express what cannot be defined, a desire for something that is not limited.

c. M. Reville: religion is the determining force of human life, a bond that unites the human mind with mysterious thoughts, which rule the world and oneself. 
d. Tylor: The first thing one should do before studying the religions of backward racial societies is to determine what a person means by religion. If religion is defined as a belief in something high and generous, several religions do not fall into this category.

Harun Nasution said that religion, seen from the point of view of the content contained in it, is a collection of procedures for serving God gathered in a book; besides that, he said that religion is a bond that must be upheld and obeyed. Several definitions and definitions of religion show how broad the scope of religion is and at the same time show how much understanding of religion is. This, in addition to offering the great attention of experts towards religion, also indicates that formulating the definition of religion is very difficult so that one understanding is not sufficient.

Starting from several definitions of religion, Harun Nasution formulated eight definitions of religion as follows:

a. Recognition of the existence of a human relationship with supernatural powers that must be obeyed.

b. Recognition of the fact of magical powers that dominate humans.

c. Reminding oneself of a form that contains mention at a source outside of humans affects their actions.

d. Belief in a supernatural power that gives rise to a particular way of life.

e. A system of behavior (code of conduct) that comes from magical powers.

f. Recognition of obligations that are believed to originate from magical powers.

g. The worship of supernatural powers arises from a feeling of weakness and fear of the mysterious forces that exist in the natural world around humans.

h. The teachings that God revealed to humans through an apostle.

Awareness of the existence of the highest form already exists in simple societies, societies that are still low on culture and have not been influenced by other cultures, and public awareness of the existence of this highest form has existed since the presence of humans on earth, thus giving rise to various forms of belief. Towards a supreme power, such as belief in a sacred and impersonal power or power, which is considered to be subtle and capable of being possessed or not possessed by objects, animals, and humans (dynamism). Or belief in the existence of spirits (Animism) [2].

In contrast to the above definition, for Durkheim, religious phenomena can be divided into two: first, belief, constituting opinions, and second, ritual, a unique form of action, which individuals and society carry out in religious communion. In Durkheim's perspective, religious people always divide their world into two separate areas: Sacred and Profan regions. Sacred things have characteristics: being considered superior, very powerful, forbidden from normal relationships, deserving of high respect, always involving significant interests, namely the interests and welfare of all groups of people, relating to matters relating to the community, fight as the main point of a clan that affects the whole community and social area. The profane site is ordinary, unattractive, minor problems, reflecting daily personal affairs, personal activities, and endeavors smaller than close personal and family life, so it is an area of personal and private experiences.

The segmentation shared by Durkheim provides an overview of how society views and defines religion. For Durkheim, what is real in culture, social life, and social facts, while religion and rites can change according to their function in the whole community. Rituals and symbols can vary, but the essence of the sacred meaning remains attached to them. This is the functional value of religion. In religious societies, symbolic sacralization is very important and serves as a benchmark for life together. 
In Indonesia, symbolic sacralization is used for various purposes. From the perspective of leaders and policymakers, the sacred symbol is used to legalize policies and shape the paradigm of society. For people who implement policies, the sacralization of characters is consumed into a religious dogma with binding power in the community. This practice develops due to the factor of "official religion," which has been legalized by the government. In social life, minority religions tend to be colonized by "official religions". The question is, is it true that the developing minority religions are not religions that teach goodness? Is it true that minority religions have a terrible influence on social life to be positioned as second-class religions?

\section{Methodology}

This study uses a qualitative approach with a descriptive analysis method. This method is used to conduct in-depth analytical tasks related to vague research problems [3]. In collecting the data using literature related to existing research problems. The data collected was then analyzed descriptively and then presented comprehensively [4].

\section{Result and Discussion}

There are only six religions in Indonesia: Islam, Christianity, Catholicism, Hinduism, Buddhism, and Confucianism. If we look at the religious context from its historical perspective, beliefs that are "recognized" are official religions, and minority religions are positioned disproportionately. Whereas in Indonesia, there are many minority religions, including local faiths, that the government has not accommodated. Local beliefs are easily labeled heretical, animist, dynamic, superstitious, and so on [5]. Even worse, adherents of local religions face discrimination in their rights as citizens. If it has entered into the realm of labeling and discrimination by citizens, it is necessary to review the definition of religion that the Indonesian government has established [6].

In Indonesia, the category "religion" has been taken and adapted to the word "religion" in theoretical paradigmatic. Many or even most Indonesian reviewers seem to think that "religion" is a literal translation word for "religion". The reality is not that simple because "religion" covers a much narrower semantic field than "religion", and for the latter, the Indonesians have to borrow the word "religion" from the Dutch language. In reality, "religion" is a concept wrapped in Sanskrit, but is a combination of the Christian view of what is considered a world religion with the Islamic understanding of what defines true religion: that is, divine revelation conveyed to a Prophet and recorded in a holy book, the legal system for those who believe in it, congregational worship, and faith in God Almighty" [7].

Elsewhere, the Study of Wilfred Cantwell Smith or Jonathan Z. Smith shows how the word "religion" (religion) was initially used only to refer to Christian faith, which was later reified and was followed by a broader reification applied to the reality of "beliefs. "Which the West found in its colonies. Reification is a process of drawing firm boundaries from a very complicated fact. Indirectly, it is not merely a process of recognizing truth, but the formation of a new entity from that reality, through the use of a category. Thus, epistemological coercion forms the ontology of "religion " [8].

The New Order used "religion" as the state ideology and at the same time as a counter ideology against communism. Religion is strictly defined so that it can be used effectively to 
get rid of the doctrine of communism. Every citizen is then obliged to have affiliation with one of the world religions recognized by the state based on this paradigm. Those who refuse association are considered supporters of communism, and as a result, they are weighed against the state. From 1965 to the 1970s, with the discourse of eliminating the ideology of communism, large-scale conversion of citizens to one of the recognized religions occurred. The religious paradigm is stated in the PNPS Law No. 1 of 1965, maintained until now [9].

In the Indonesian context, the world religion paradigm has positioned local religions as religions with conservative, animist, dynamic teachings and practices, and various other pejorative terminologies. Because of their influence that extends to political policy, local religious traditions are often described as conservative practices that must be modernized, shirk practices that must be abandoned, infidel practices that must be eradicated, and so on. Furthermore, in discussing religion with this paradigm, local religious practices are often conceptualized as "culture" and not religion. "Culture" is understood as something "profane" in contrast to belief as something "sacred". Again, the influence of this religious paradigm is hegemonic, even to those who remain loyal to their local religion.

The issues described above demonstrate the importance of examining more deeply the paradigm of world religion. It is important to emphasize that the paradigm of world religions lies in the "perspective" of scholars to understand and explain what can be categorized as world religions. The problem is not with world religions such as Islam, Christianity, Hinduism, Buddhism, Confucianism, etc., or how these religions describe and represent themselves. That political factors dominate the paradigm construction of world religions, and as a result, there are misrepresentations of local beliefs and even those categorized as world religions themselves.

In Indonesia today, politics greatly influence religious and customary discourse. Religion is constructed by dominant powers such as the state, mainstream religious groups (the majority). On the other hand, the human right to choose and embrace religion is guaranteed by the 1945 constitution, which affects local faiths that do not get their rights as citizens. Religious minorities are still alienated from their rights, accompanied by continuous discrimination [10].

The explanation of a religious phenomenon, or even the presence of religion in a phenomenon, needs to consider these two things. This approach can be applied in various subfields of religious studies, such as in the study of religion and science, religion and ecology, interreligious dialogue, etc [11]. There are several goals to be achieved in the discussion of everyday faith. Everyday religion brings back the original problem of definition because it indirectly attempts to overcome the deadlock by discussing how "religion" should be defined. That is, it does not establish a report before the study is undertaken. It attempts to cast a wide enough net to help find "religion" as lived by individuals and communities, not as defined by dominant political power or by researchers [12].

The approach of everyday religion may be able to break the anxiety of definition. Suppose a description is deemed necessary to identify what "thing" a religious reviewer will study in this approach. In that case, the principals (agencies) define it themselves: how people relate to things that they experience as "religious". Then, the definition of religion becomes part of the study, not a prerequisite; it is not the research area but the subject under investigation. The everyday religion approach is presented here as an example of creative ways to overcome some difficulties in defining religion. We want to emphasize not the superiority of this approach itself but its innovative efforts to develop belief definitively by expanding its territory by developing paradigms, freeing it from a priori categories. Therefore, a redefinition of religion is needed so that in practice, it does not castrate minority religions, which are 
developing and exist in Indonesia (including local religions). The expansion of the paradigm in questioning the definition of religion can be an alternative solution to redefine religion so that there is no longer "government religion," "majority," and "minority" in seeing religion in Indonesia.

\section{Conclusion}

The definition of religion needs to be placed in its portion, separated from legitimacy and power, to get the essence of belief, not just dwelling on religious attributes. When the spirit of religion is obtained, space for local religion can be accommodated in social life. Religion is no longer judged by its characteristics and packaging but is constructed from its religious actors accompanied by its religiosity. The expansion of the paradigm that will be carried out will merge problems related to "majority" and "minority" religions and government religions with local beliefs. When the paradigm of the definition of religion can be expanded, conflicts in society triggered by religion can unravel, and state services to the community can run well and optimally.

\section{References}

[1] FJ Nugroho, Reconstruction of Post-Conflict Rituals in the Religious Tourism Object of Mount Kemukus, Sragen Regency, Central Java. Salatiga: SWCU Theology Faculty, 2017.

[2] FJ Nugroho and AD Rengganis, "ECOLOGICAL MITIGATION IN THE KEMUKUS MOUNTAIN RELIGIOUS TOURISM OBJECT," Reli. J. Stud. Religions, vol. 16, no. 1, Jun. 2020, DOI: 10.14421 / rejusta.2020.1601-01.

[3] Sugiyono, Understanding Qualitative Research . Bandung: Alfabeta, 2012.

[4] LL Moleong, Qualitative Research Methods . Bandung: PT Remaja Rosdakarya, 2004.

[5] AZ Fitri, "Harmonious Interaction Patterns between Myths, Sacred, and Local Wisdom of the Pasuruan Community," El-HARAKAH (ACCREDITED), Dec. 2012, DOI: 10.18860 / el.v0i0.2198.

[6] M. Taufik, "SOCIO-RELIGIOUS VALUE OF SOCIETY IN INTERACTION IN YOGYAKARTA INTERACTION STUDY," Khazanah J. Stud. Islam and Hum., vol. 16, no. 1, p. 49, Sep. 2018, DOI: 10.18592 / khazanah.v16i1.2056.

[7] M. Picard and R. Madinier, Politics of Religion in Indonesia - Syncretism, Orthodoxy and Religious Contention in Java and Bali. New York: Routledge, 2011.

[8] S. Maarif, "Indigenous Religion of Ammatoa of Sulawesi, Indonesia: Ethical Ways of Relationship among Persons of Different Beings," in Local Religion, vol. 3, no. 2, Yogyakarta: CRCS - Graduate School of Gadjah Mada University, 2015, pp. 54-67.

[9] Fatmawati, "PROTECTION OF THE RIGHT TO FREEDOM OF RELIGION AND SERVICE IN THE STATE OF INDONESIAN LAW," J. Constitution, vol. 8, no. 4, pp. 490-520, 2011.

[10] Sukirno, "Discrimination of Fulfillment of Civil Rights for Adherents of Local Religions," Adm. Law Gov. J., vol. 1, no. 3, pp. 231-239, 2018, [Online]. Available: https://ejournal2.undip.ac.id/index.php/alj/article/view/3804/2123. 
[11] SM Jannah and M. Nawir, "Harmonization of Religion (Case Study of Religious Coexistence in Lamasi District, Luwu Regency)," Equilib. J. Educator., 2019, DOI: 10.26618 / equilibrium.v6i2.2595.

[12] M. Dahlan and A. Liemanto, "Legal Protection of the Constitutional Rights of Adherents of Local Religions in Indonesia," Arena Huk., vol. 10, no. 1, pp. 20-39, 2017, DOI: 10.21776 / ub. Because of the law. 2017.01001.2. 